\title{
The effect of antibacterial synergism of silver nanoparticles with extract of Urtica dioica and Allium hirtifolum against multidrug resistant klebsiella (MDR) isolated from ICU patients
}

\author{
Mahsa Dadgarl, Akram Sadat Tabatabaee Bafroee $^{2}$, Sara Minaeian ${ }^{3}$ \\ ${ }^{1}$ MSc, Department of Biology, East Tehran Branch, Islamic Azad University, Tehran, Iran \\ ${ }^{2}$ Assistant professor, Department of Biology, East Tehran Branch, Islamic Azad University, Tehran, Iran \\ ${ }^{3}$ Assistant professor, Antimicrobial Resistance Research Center, Institute of Immunology and Infectious Diseases, Iran \\ University of Medical Sciences, Tehran, Iran
}

\begin{abstract}
Background: Because most bacteria responsible for hospital infections are resistant to common antibiotics, the tendency to produce effective and nontoxic anti-microbial drugs have increased. Therefore, it is attempted to substitute antibiotics with natural products, such as nanoparticles and plant extracts. The aim of this study was to investigate the synergistic antibacterial effects of silver nanoparticles with extracts of nettle and shallot plants against multi drug resistant (MDR) kebsiella.

Materials and methods: Of 360 clinical samples, 112 kebsiella were isolated from ICU hospitalized patients. The klebsiella isolates were identified by biochemical tests. The antibiotic susceptibility of isolates was determined using disc diffusion method. Minimum inhibitory concentration of silver nanoparticles, nettle and shallot extracts against resistant isolates was assessed by broth microdilution method and their synergitic effects were determined using checkerboard method. Also the fractional inhibition concentration (FIC) was calculated.

Results: The silver nanoparticles were more effective than plant extracts against MDR isolates. The use of silver nanoparticles and shallot extract together led to synergistic effect on both MDR klebsiella isolate and Klebsiella pneumoniae ATCC 1290. In addition, the use of the silver nanoparticles and nettel extract led to synergistic effect on MDR isolate of klebsiella and additive effect ATCC isolate.

Conclusion: Due to good antibacterial effect of AgNPs, shallot and nettle extracts on resistant klebsiella isolates and their affordable production, they can be exploited in addition to antibiotic treatments.

Keywords: Silver nanoparticles, Shallot extract, Nettle extract, Klebsiella, MDR.

Cited as: Dadgar M, Tabatabaee Bafroee AS, Minaeian S. The Effect of Antibacterial Synergism of Silver Nanoparticles with Extract of Urtica dioica and Allium hirtifolum against Multidrug Resistant Klebsiella (MDR) isolated from Patients in ICU. Medical Science Journal of Islamic Azad University, Tehran Medical Branch 2019; 29(2): 131-140.
\end{abstract}

Correspondence to: Akram Sadat Tabatabaee Bafroee

Tel: +989126852282

E-mail: akram_tabatabaee@yahoo.com

ORCID ID: 0000-0003-0309-2206

Received: 30 May 2018; Accepted: 13 Jan 2019 
مجله علوم يزشكى دانشعاه آزاد اسلامى

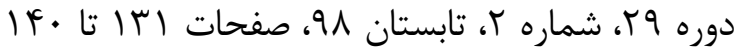

Original

Article

\title{
اثر سينرزيسم ضدباكتريايى نانوذرات نقره با عصاره گياهان گزنه و موسير عليه
} كلبسيلاى مقاوم به جند دارو (MDR) جدا شده از بيماران بخش مراقبتهاى ويزه

\author{
مهسا دادكر '، اكرم سادات طباطبايیى بفرويى'، سارا مينائيان'
}

'دانش آموخته كارشناسى ارشد، كروه زيست شناسى، واحد تهر ان شرق، دانشكاه ازاد اسلامى، تهران، ايران

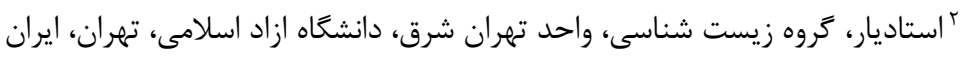

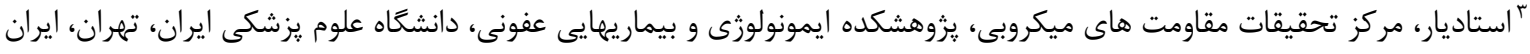
جـكيده سابقه و هدف: به دليل / ينكه بيشتر باكترىهاى مولد عفونتهاى بيمارستانى به انتىبيوتيكهاى رايج مقاوم هستند، كرايش به توليد

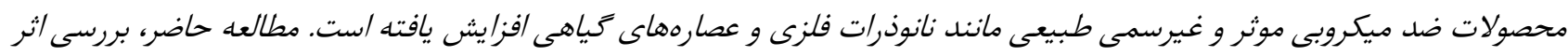

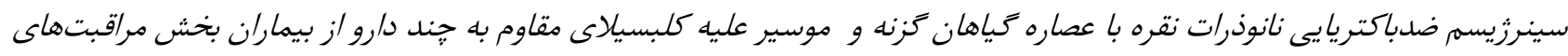
ويزه رامورد هدف قرار داد.

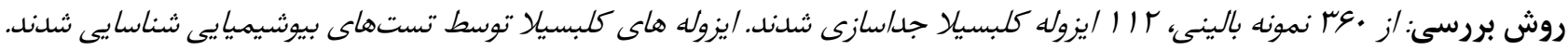

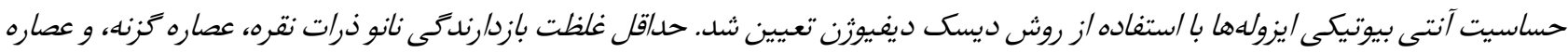

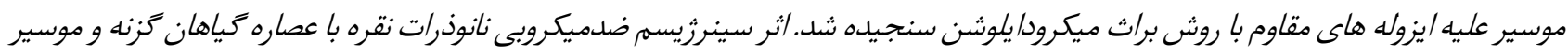

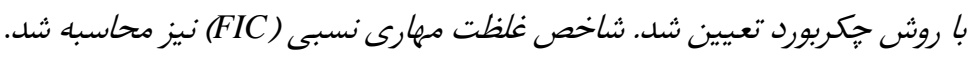
يافته ها: تاثير بيشتر نانوذرات نقره، نسبت به عصارهاى حياهى، عليه / يزولههاى كلبسيلاهاى MDR مشاهده شد. ستنفاده توام نانوذرات نقره و

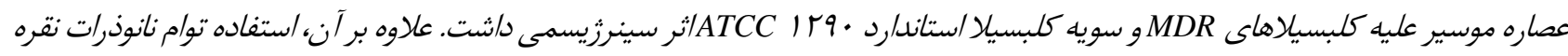

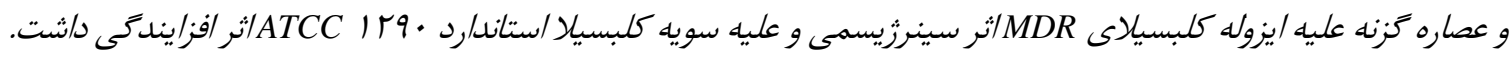

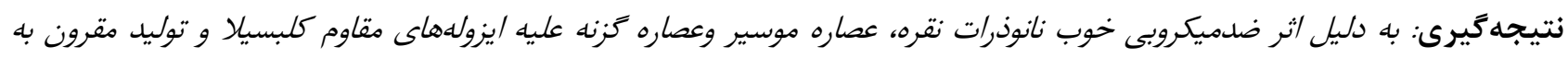

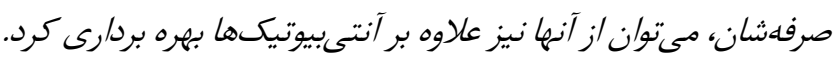

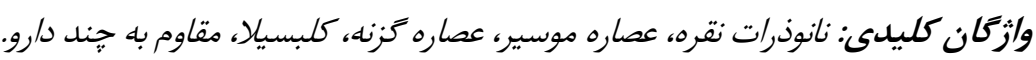

بيمارستان از طريق تماس با ناقلين و قطرات معلق در هوا مقدمه

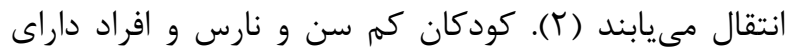
بيمارىهاى زمينهاى مستعد ابتلا به عفونت بيمارستانى

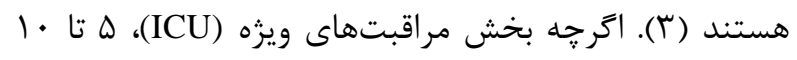

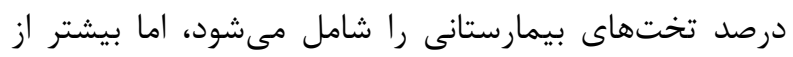

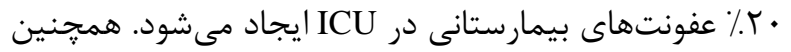

عفونت بيمارستانى به عفونتى اطلاق مى شود كه بيمار در زمان

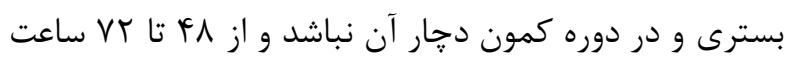

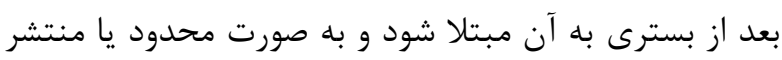

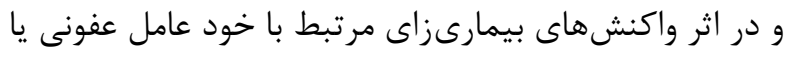

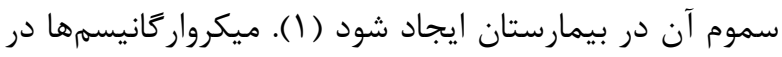


عــلاوه بر كياهان دارويى، امـــروزه كاربرد نانــوتكنولــوزى

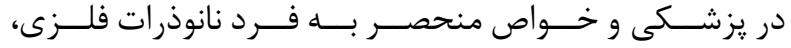

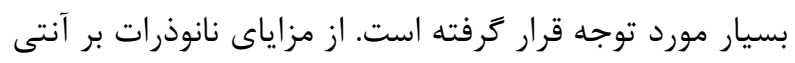

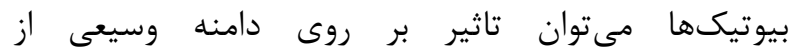
ميكروار كانيسمها، مقاوم نشدن باكترىها نسبت به نانوذرات و

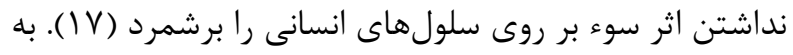

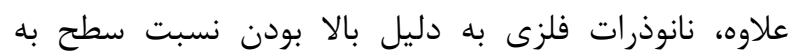
حجمشان، سطح تماس بيشترى را با باكترىها برقرار كرده،

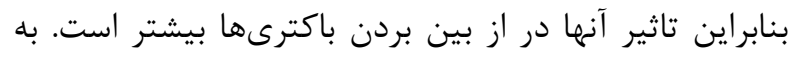

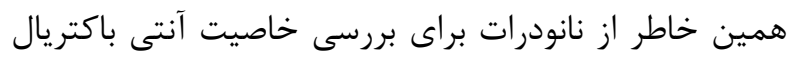
استفاده مىشود. به نظر مىرسد كه از ميان نانوذرات فلزى، نانوذرات نقره، نقش مهمى را درمقابله با ميكروبهاى مقاوم

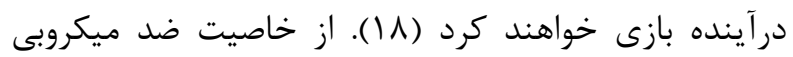
نانوذرات نقره براى از بين بردن طيف وسيعى از باكترىها، مخمرها، قارجها و ويروس ها استفاده مىشود (9 ()). تحقيقات نشان مى مهند كه خاصيت باكترى كشى نقره به دليل آسيب هايى است كه در غشا سلولى باكترىها ايجاد مى كند ( • (؟). با توجه به اينكه تحقيقات كذشته نشان دادهاند استفاده تركيبى از عوامل ضد ميكروبى نسبت به استفاده از هر يك از عوامل به تنهايى داراى خاصيت ميكروب كشى بيشترى است (Y)، در اين يثوهش اثر ضد ميكروبى نانو ذرات نقره، عصاره موسير و عصاره كزنه به تنهايى و به صورت تركيبى بررسى

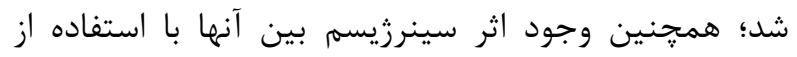
حداقل غلظت مهارى مشترى (FIC) مورد يزوهش قرار گرفت

\section{مواد و روشهها - مواد مواد و محيطهاى كشت}

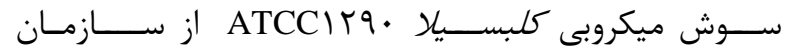
يزوهشهاى علمى صنعتى ايران تهيه شد. عصارههاى موسير و كزنه از شركت ابن ماسويه تهيه شدند. نيترات نقره، سديم بور

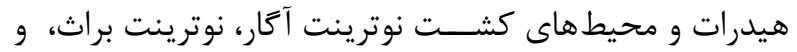

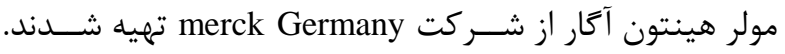

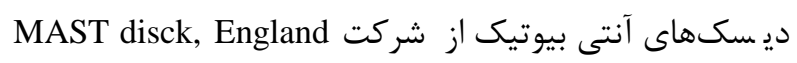

تهيه شدند.

\section{جمع آورى نمونه، جداسازى و شناسايى تُني}

اين مطالعه توصــيفى - مقطعى در بيمارســتان آموزشــى آنى

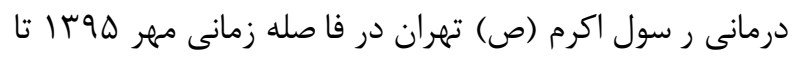

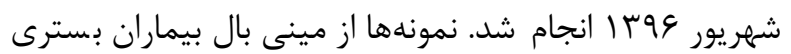

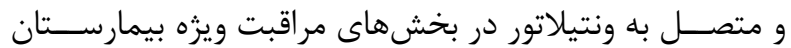

اين عفونتها باعث افزايش مورتاليته (مرى و مير) و هزينهها

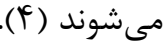
كلبسيلا ينومونيه، باكترى گرم منفى از خانواده انتروباكترياسه است كه اغلب در مجارى تنفسى فوقانى و مجراى گوارشى تومى بهى يافت مىشود و يكى از شايعترين عوامل ايجاد عفونتهاى

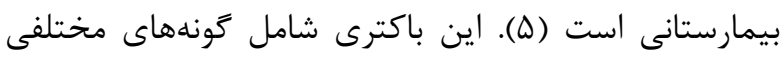

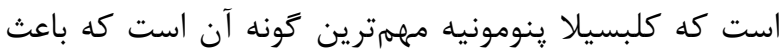
ينومونى، عفونت دستخاه ادرارى و عفونت بيمارستانى مىشود

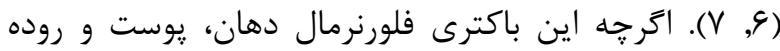

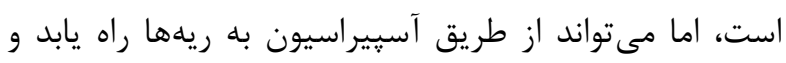
موجب ينومونى شود. ينومونى كلبسيلايى در افراد بسترى در بيمارستان و افراد داراى ضعف ايمنى ديده مىشود؛ بنابراين مقاومت آنتى بيوتيكى در اين باكترى تهديدى جدى

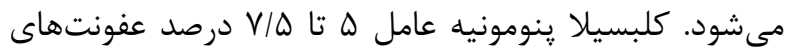

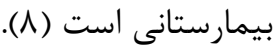
يس از كذشت دهdهاى بسيار از نخستين بيمارى كه با آنتى

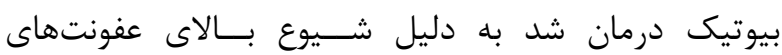

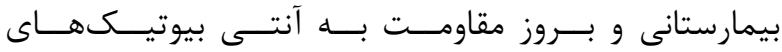

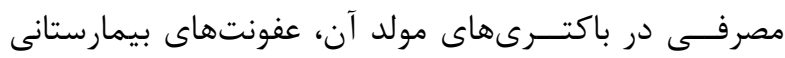

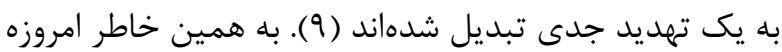
سعى مىشود براى جلوگيرى از اين مشكل از روشهاى جديد

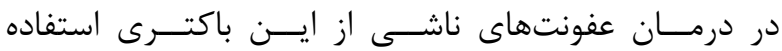

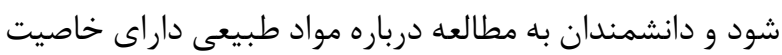
آنتى باكتريال بيشتر و عوارض جانبى كمتر مانند عصارههاى گَياهى و نانوذرات فلزى علاقه نشان دهند. بنابر اين، ريش بيش بينى

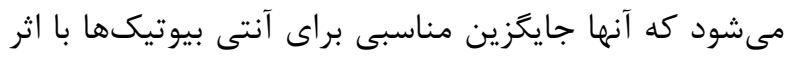
كمتر و عوارض جانبى بيشتر باشند (• (1). موسير (shallot) با نام علمى Allium hertifolium متعلق به جنس Allium و خانواده لاله سانان Siliaceae يكى از خياهان دارويى مهم داراى خاصيت آنتى باكتريال است (1 (1). موسير به دليل دارابودن تركيبات اركانوسولفور و دى آليل سولفيد و دى آليل دى سولفيد داراى خاصيت ضدباكتريايى است (r ا,

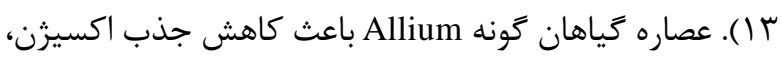

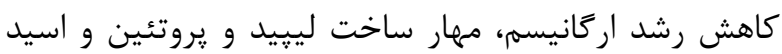
نو كلئيك و تخريب غشا مىشود (f ( ). ززنه، ديخر زياه دارويى

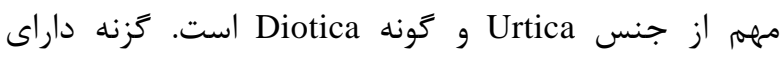
سايونين است كه فعاليتهاى دارويى آن مانند اثر آنتى بيوتيكى عليه باكترىهاى گرم مثبت و منفى ززارش شده

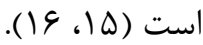


تعيين حداقل غلظت بازدارندكى (MIC) براى عصــاره كز نه، عصـــاره موســير و نانوذرات نقره به روش براث ميكرودايلوشن

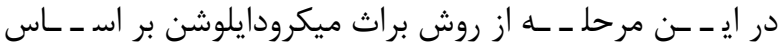

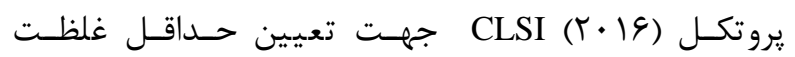

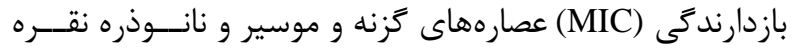

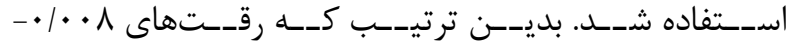

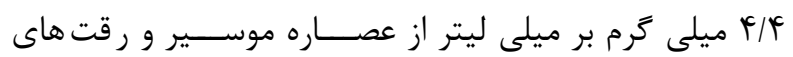

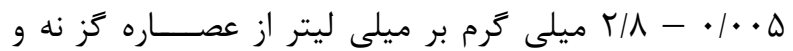
رقتهاى •ه - 9 • • • ميلى كرم بر ميلى ليتر از نانوذرات نقره

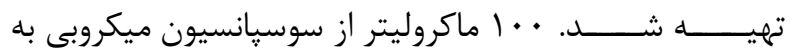
محيط مولر هينتون براث حاوى غلظتهاى مختلف از عصـاره

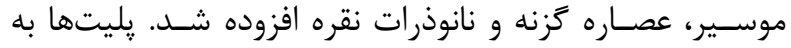

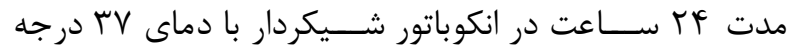

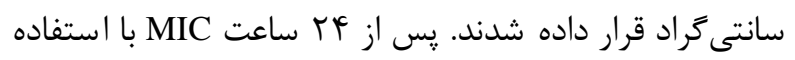

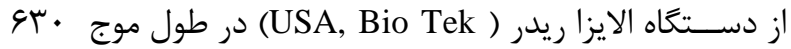

نانومتر تعيين شد (TY). بر همكنش ضد ميكروبى تركيب عصاره هر يك از تياهان

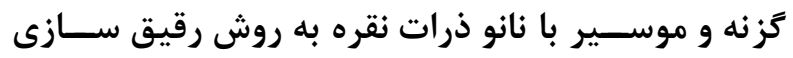
جكربورد براى بررسـى برهمكنش ضـــ ميكروبى هر يك از عصـارههاى

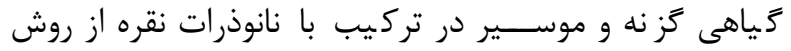

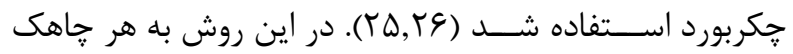

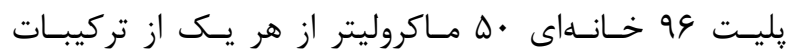

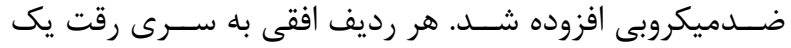

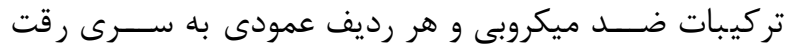

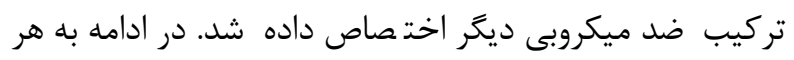
קاهك . .1 ماكروليتر سو سيانسيون ميكروبى افزوده شد. هر يليت حاوى كنترلهاى مثبت و منفى بود. خاهك هاى كنترل

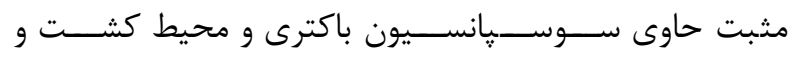

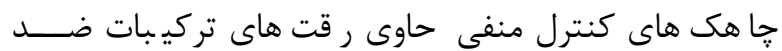

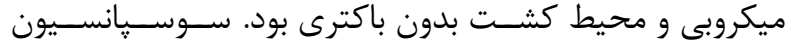

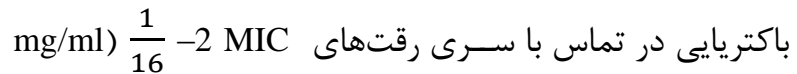

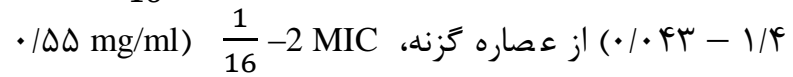

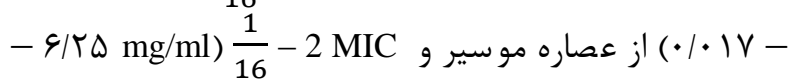

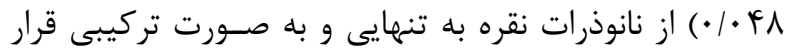

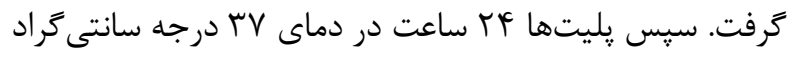

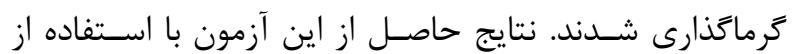
فرمول زير و محاسبه غلظت بازدارنده كسرى(FIC) بيان شد.
جمع آورى و در محيطهاى نوترينت آكار و شكلات اتار كشت

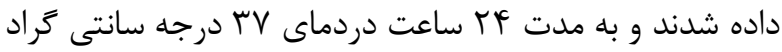
كرماكذارى شدند. كلونىهاى مشكوى به كلبسيلا با استفاده از تستهاى بيو شيميايى متداول، شامل آزمايش احياء نيترات،

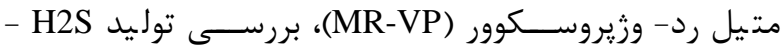

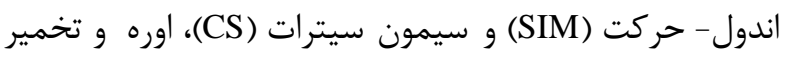
كلوكز در محيط ترييل شوكر ايرن احار (TSI)) تاييد شدند.

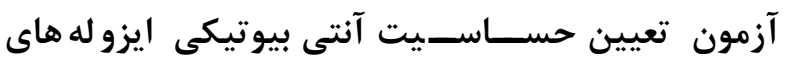
كلبسيلا

تعيين حساسيت ايزولهها نسبت به آنتى بيوتيكهاى مختلف با

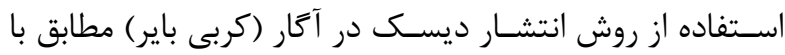

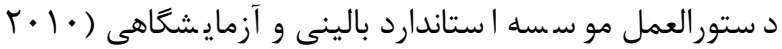
(CLSI

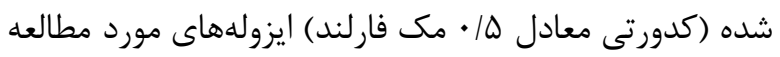

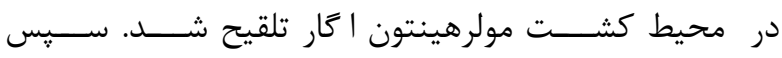

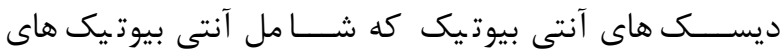

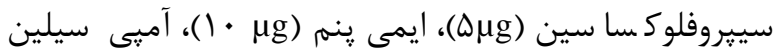

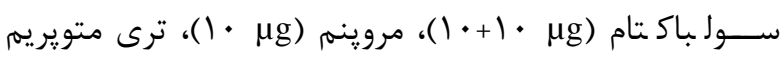

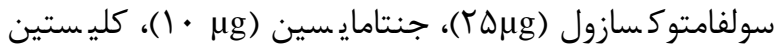

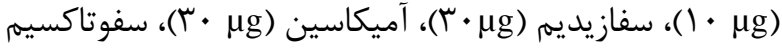

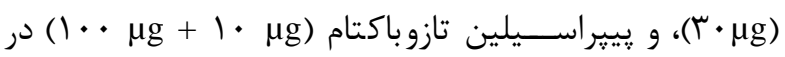
فواصل مشخص روى محيط كشت قرار داده شدند و يليتها به

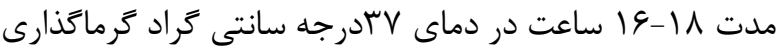

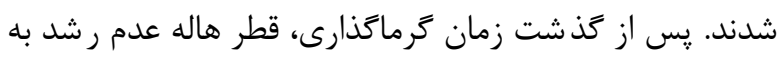

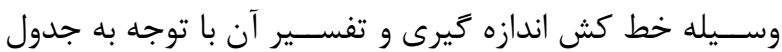
براى/شرشياكلى صورت گرفت. سويه استاندارد كلبسيلا ينمونيه • ATCCIY نيز عنوان كنترل مثبت در نظر كرفته

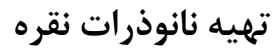
• • ميلى ليتر نيترات نقره (

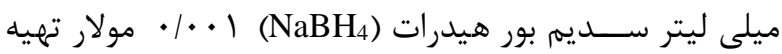

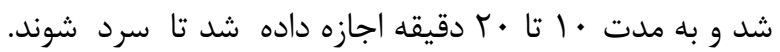

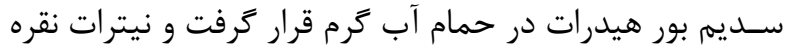
به صورت قطره قطره اضافه شد و همزمان با سرعت بالا همزده

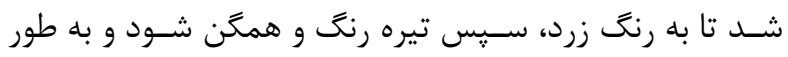

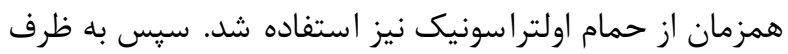

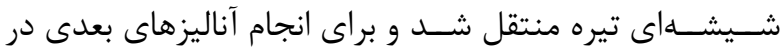

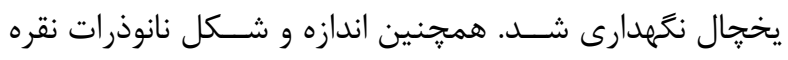

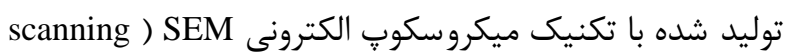
(electron microscope 
الكوى مقاومت آنتى بيوتيكى ايزوله هاى كلبسيلا درصد مقاومت ايزولههاى كلبسيلا در جدول آلئي آمده است.

\begin{tabular}{|c|c|c|c|}
\hline مقاوم & 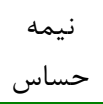 & حساس & آنتى بيوتيكها \\
\hline $\begin{array}{c}\text { Tr/TY } \\
\%\end{array}$ & - & $\% \mathrm{VV} / \mathrm{VV}$ & $\begin{array}{r}\text { Piperacilin Tazobactam } \\
\text { (PTZ110) }\end{array}$ \\
\hline$\% V / F$ & - & $\% q r / 09$ & $\begin{array}{r}\text { Cefotaxim } \\
(\text { CTX30) }\end{array}$ \\
\hline $\begin{array}{c}|N / D| \\
\%\end{array}$ & - & $\% \wedge 1 / 4 \wedge$ & $\begin{array}{r}\text { Amikacin } \\
\text { (AN30) }\end{array}$ \\
\hline $\begin{array}{c}11 / 11 \\
\%\end{array}$ & - & $\% \wedge \Lambda / \wedge \Lambda$ & $\begin{array}{r}\text { Ceftazidime } \\
(\text { CAZ30) }\end{array}$ \\
\hline $\begin{array}{c}11 / 11 \\
\%\end{array}$ & - & 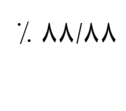 & $\begin{array}{r}\text { Colistin } \\
(\text { CL10) }\end{array}$ \\
\hline$\% r / V$ & - & $\% ৭ 9 / 4 q$ & $\begin{array}{r}\text { Gentamicin } \\
\text { (GM10) }\end{array}$ \\
\hline $\begin{array}{c}\text { rQ/৭Q } \\
\%\end{array}$ & - & $\% v \cdot 1 \cdot q$ & $\begin{array}{r}\text { Trimethoprim } \\
\text { sulfamethoxazole } \\
(\mathrm{SXT})\end{array}$ \\
\hline $\begin{array}{c}\% \\
\text { TT/TT }\end{array}$ & - & $\% \mathrm{VV} / \mathrm{VV}$ & $\begin{array}{r}\text { Meropenem } \\
\text { (MEN10) }\end{array}$ \\
\hline$\% r / V$ & $\% r / V$ & $\% 9 r / 09$ & $\begin{array}{r}\text { Ampicillin sulbactam } \\
\text { (SAM) }\end{array}$ \\
\hline $\begin{array}{c}\mu r / \mu r \\
\%\end{array}$ & $\% r / V$ & $\% .95 / 99$ & $\begin{array}{r}\text { Imipenem } \\
\text { (IMI) }\end{array}$ \\
\hline$\% r / V$ & - & $\% १ ९ / ४ q$ & $\begin{array}{r}\text { Ciprofloxacin } \\
\text { (CP5) }\end{array}$ \\
\hline
\end{tabular}

از ميان آنها ايزولههاى MDR نسبت به آنتىبيوتيكهاى خانواده

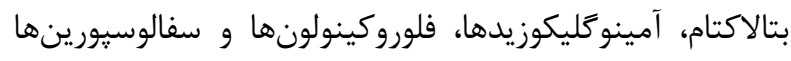

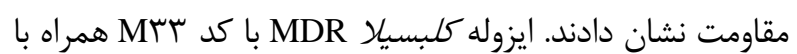

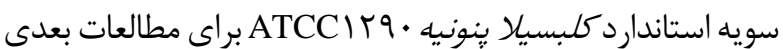

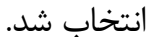
نتايج بررسى نانوذرات نقره سنتز شده

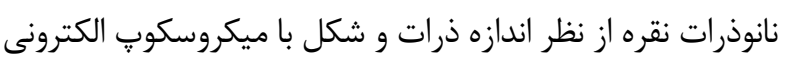
نكاره (SEM) بررسى شدند (شكل ז). نتايج ميكروسكوب

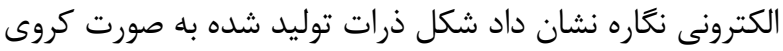

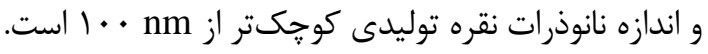
نتايج تعيين حداقل غلظت بازدارندكى (MIC) براى عصاره كزنه، عصاره موسير و نانوذرات نقره بر اساس نتايج مربوط به تعيين حداقل غلظت بازدارندكى

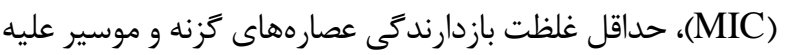

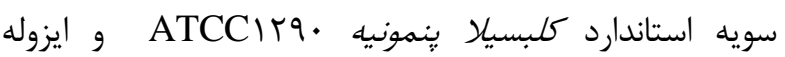

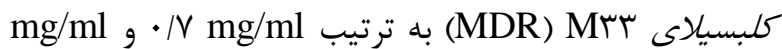

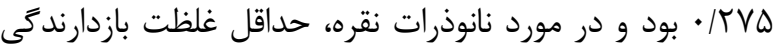

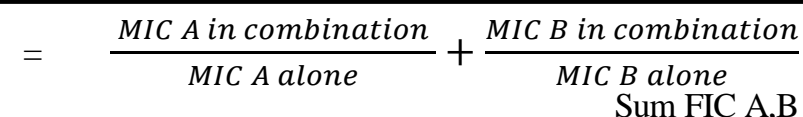

مجموع غلظت بازدارندگى كسرى عصاره گياهى:Sum FIC A,B

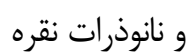
حداقل غلظت بازدارندَى عصاره گياهى :حIC A :حداقل غلظت بازدارندگى نانوذرات نقره :حIC B

پس از محاسبه FIC نتايج آن به صورت زير تفسير شد: مقادير كمتر از 9/ • زشان دهنده اثر سينرزيسهم، مقادير بين 9.

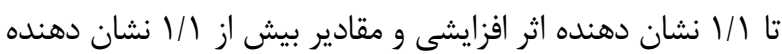

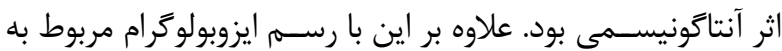

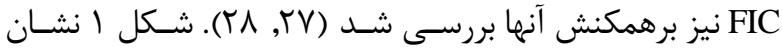

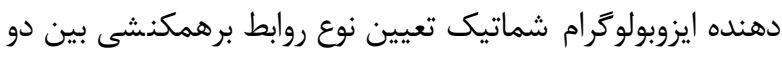

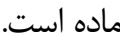

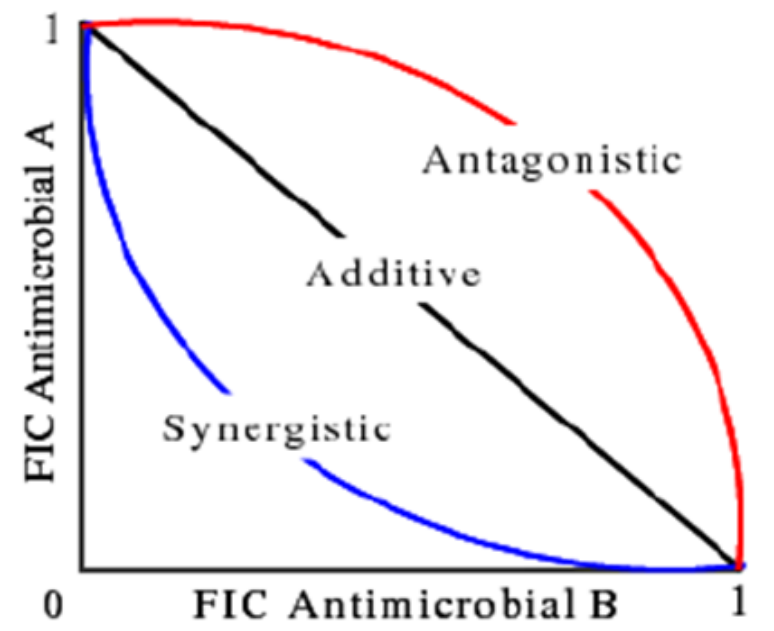

شكلا. ايزوبولو گرام شماتيك تعيين نوع روابط برهمكنشى بين

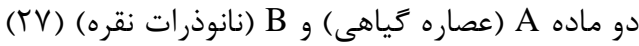

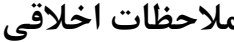

در اين مقاله، موافقت كميته اخلاق در يزوهش دانشعاه آزاد

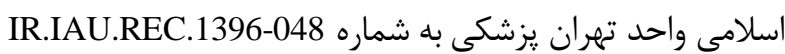
كرفته شد و همه مصوبات آن رعايت شد.

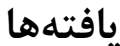

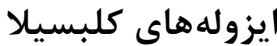
از • عب نمونه جمع آورى شده از مينى بال بيماران بسترى و متصل به ونتيلاتور بخش هاى مراقبتهاى ويزه بيمارستان آندان

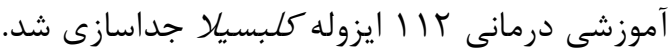


بيمارستان بسترى هستند. بخش ICU ICU دليل داشتن بيش از • ب ٪ عفونتها در بين بخشهاى مختلف بيمارستان از اهميت بيشترى برخوردار است. به دليل افزايش بـ بهن

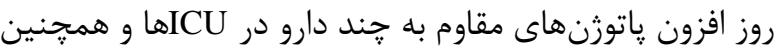
كاهش حساسيت به آنتى بيوتيكها در ايزولههاى باكتريايى به به به به به

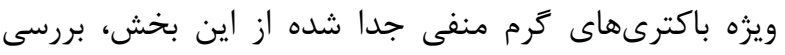
عفونتهاى بيمارستانى از اهميت بالايى برخوردار است (9 ب).

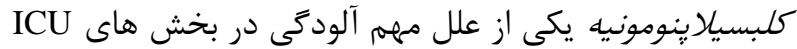
است و احتمالا در آينده منجر به ايجاد مشكلات جدى در زمئه زمينه

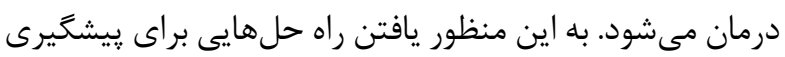
و مقابله با عفونتهاى كلبسيلايى، به خصوص در بخشهاى ICU

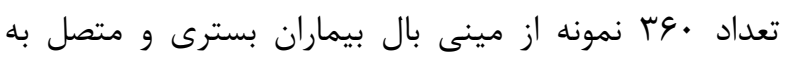

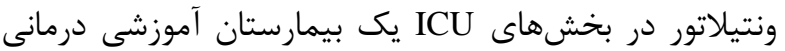

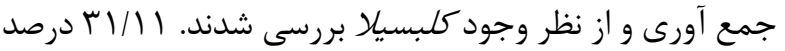
از ايزولهها، كلبسيلا تشخيص داده شدند كه دومين عامل عفونت بعد از اسينتوباكتر در آن بيمارستان شناسايى شد. ايزولهدهاى مورد بررسى نسبت به آنتىبيوتيكهاى خانواده بتالاكتام، بيمارسيان آمينو مَليكوزيدها، فلوروكينولونها و سفالوسيورينها مقاومت نشان دادند. در مطالعهاى كه توسط Panah و همكارانش در

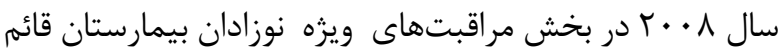
مشهد انجام شد، فراوانى ايزولههاى باكتريايى كلبسيلايى

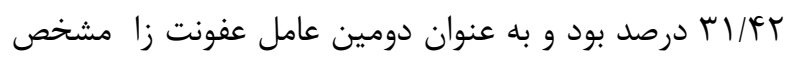
شد (آr). در مطالعهاى كه توسط Shojaei و همكارانش در سال

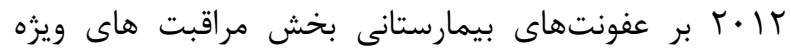
بيمارستان نكويى قم انجام شد، كلبسيلا به عنوان دومين عامل

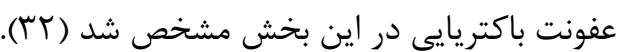

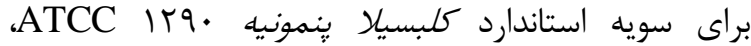

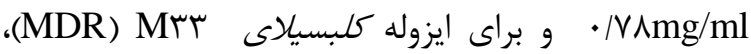

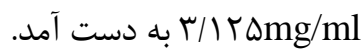

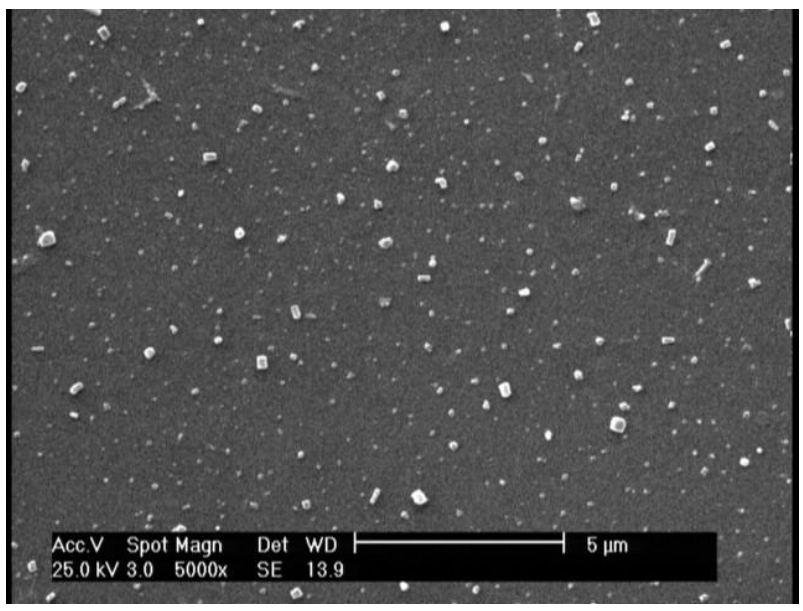

شكل r. شكل و اندازه ذرات نانوذره نقره سنتز شده توسط ميكروسكوٍ الكترونى نعاره

نتايج بر همكنش ضد ميكروبى تر كيب عصاره هر يك از گ گياهان گَزنه و موسير با نانو ذرات جدولهاى r و r نتايج FIC تركيب عصاره موسير و نانوذرات نقره، عصاره ززنه و نانوذرات نقره عليه ايزوله كلبسيلا سب MDR) M و سويه استاندارد كلبسيلا ينومونيه

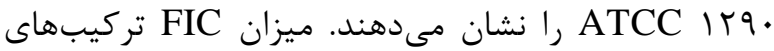

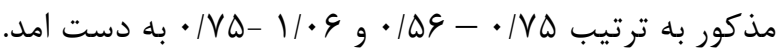

\section{بحث}

امروزه عفونتهاى بيمارستانى در دنيا شيوع بالايى دارند و جان

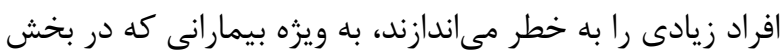

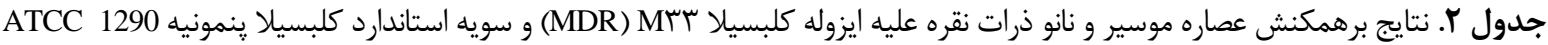

\begin{tabular}{|c|c|c|c|c|}
\hline 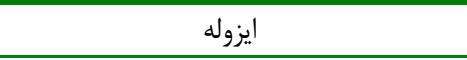 & موسيرFIC & نانوذرات نقره FIC & FIC index & نتيجه برهمكنش \\
\hline ايزوله كلبسيلا سr(MDR (M M & $\cdot / 0$ & $\cdot 1 \cdot 9$ & $\cdot \mid \Delta \Phi$ & 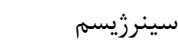 \\
\hline ATCC IY • سويه استاندارد كلبسيلا ينمونيه & $\cdot 10$ & $\cdot / T \Delta$ & $\cdot / V \Delta$ & 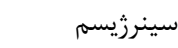 \\
\hline
\end{tabular}

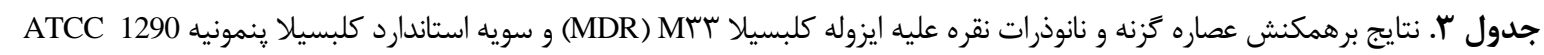

\begin{tabular}{|c|c|c|c|c|}
\hline 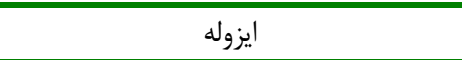 & SFFIC & نانوذرات نقره FIC & FIC index & نتيجه برهمكنش \\
\hline ايزوله كلبسيلا rس(MDR & $\cdot / R \Delta$ & $\cdot 10$ & $\cdot / V \Delta$ & سينرزيسم \\
\hline ATCCI Yq • سويه استاندارد كلبسيلا پِنمونيه & 1 & .1 .9 & $1 / \cdot 9$ & افزاينده (Additive) \\
\hline
\end{tabular}


كلبسيلاى مقاوم به هند دارو، اثر ضدميكروبى فرم تركيبى

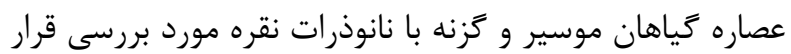

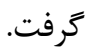
نتايج تستهاى براث ميكرودايلوشن، فعاليت ضدميكروبى

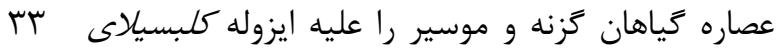

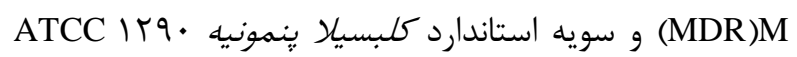

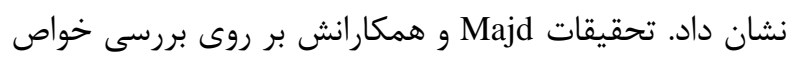

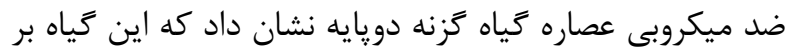

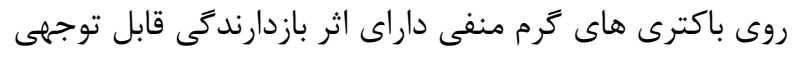

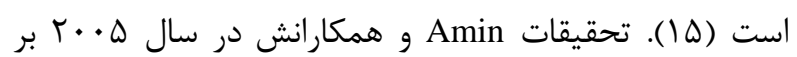
روى خواص ضد ميكروبى عصاره موسير تاييد كننده تحقيق

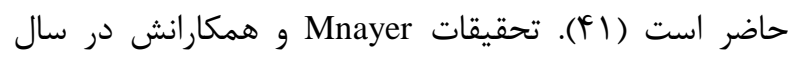

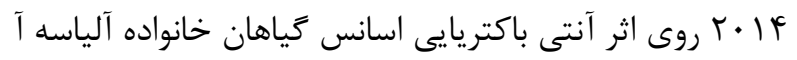
مانند shallot نشان داد اسانس shallot اثر مهاركنند روى باكترى هاى كرم مثبت و كرم منفى دارد كه تاييد كننده تحقيق حاضر است (Y) (F). همجنين تست براث ميكرودايلوشن نشان داد كه نانوذرات نقره

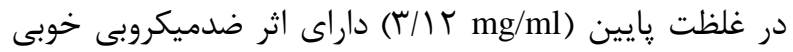
عليه ايزوله كلبسيلاى (MDR) Mrr) و سويه استاندارد

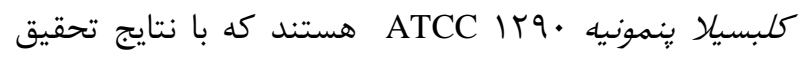

Franci

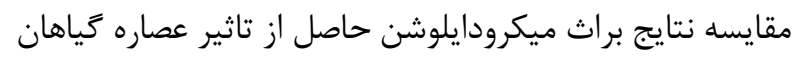

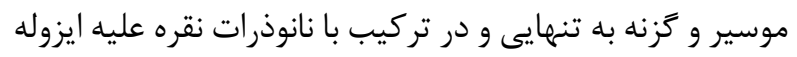

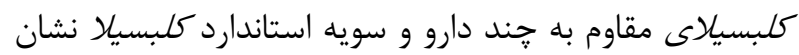

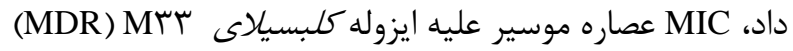

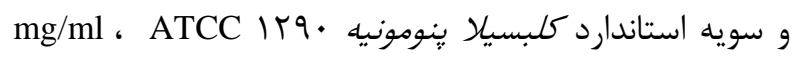

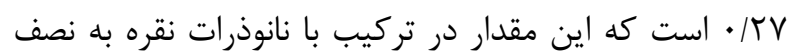
(MIC عصاره تزنه عليه

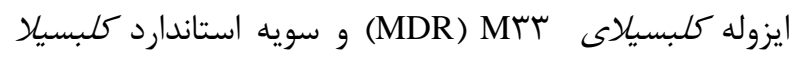

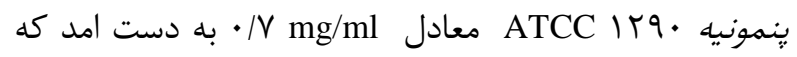
اين مقادير در تركيب با نانوذرات نقره براى ايزوله كلبسيلاى به به ميزان يك جهارم (MDR) Mr M

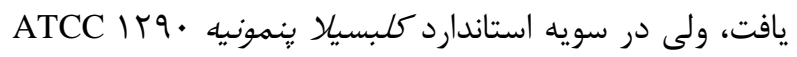
بدون تغيير ( /Vmg/ml•) بود. MIC نانوذرات نقره عليه ايزوله

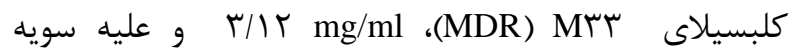

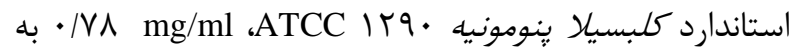
دست آمد. اين مقادير در تركيب با عصاره هر يك از كياهان

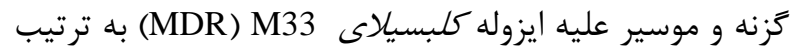

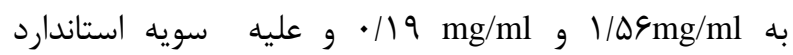

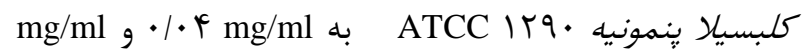

به دليل افزايش مقاومت باكترىها نسبت به آنتى بيوتيكها، توجه به طب سنتى و گياهان دارويى براى درمان بيمارىها و واني

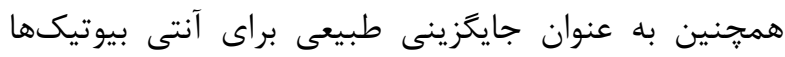

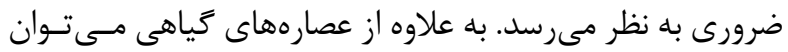

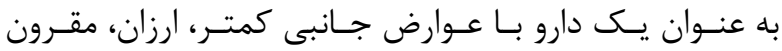

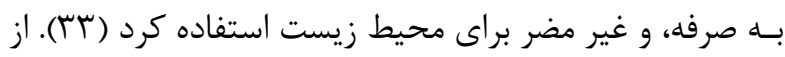
جمله اين كياهان مى توان به كياه كزنه و موسير اشاره كرد. كزئه

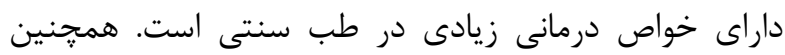

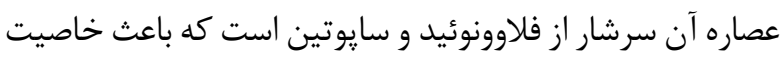

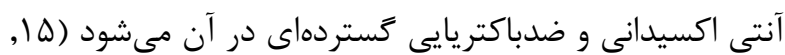
تاك تاكنون براى غلبه بر عفونتها مورد استفاده قرار كرفته است آرتان همينين به دليل داشتن مواد موثره اركانوسولفور و دى دى آليل سولفيد و دى آليل دى سولفيد داراى خواص ضد باكتريايى و ضد قارجى است. استفاده از عصاره اين خياه به علت فعاليتهاي

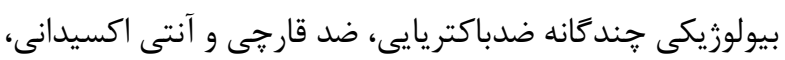
در صنايع دارويى بسيار مورد توجه قراركرفته است (هـآ).

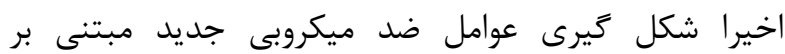

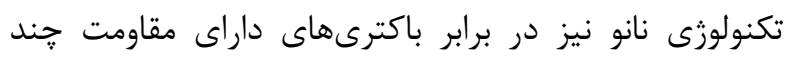

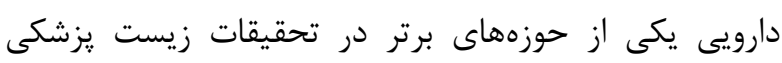

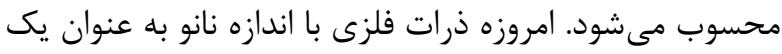
جايكزين موفق درمان آنتى بيوتيكى شناخته شدهاند، زيرا داراى

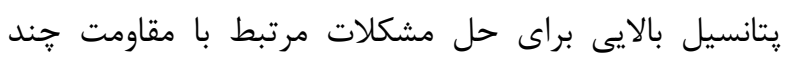

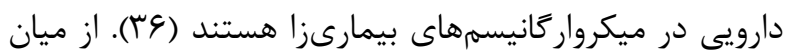

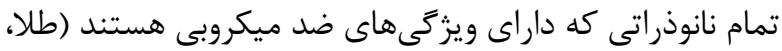

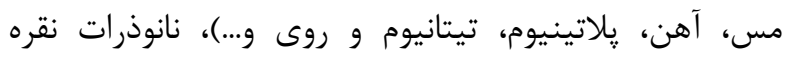

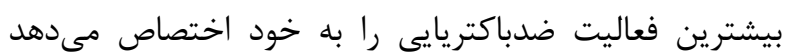

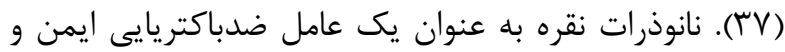
موفق در برابر باكترى هاى مقاوم در برابر داروها تلقى مى نى ندوند

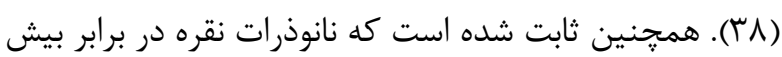
از •90 ميكروار كانيسم از جمله باكترىها (كرم مثبت و كرم منفى)، قارجها و ويروسها موثر هستند (ج)م). البته هنوز

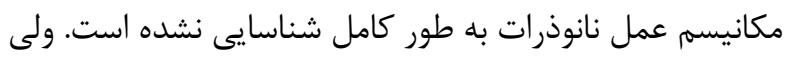
به نظر مىرسد، نانوذرات با قابليت اتصال به غشاء باكترى و فعل

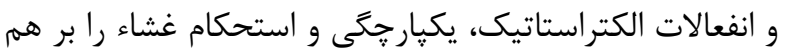

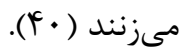
تاكنون، فعاليت ضدميكروبى عصاره هاى كياهى موسير و گزنانه در تركيب با نانوذرات نقره عليه ايزوله هاى كلبسيلا مقاوم به

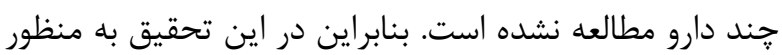
دست يابى به تركيب ضد ميكروبى با اثربخشى بيشتر عليه 
ييـش بينى كرد كه با توجه به اختلالى كه نانوذرات در ديواره سلولى و غشاء سيتويلاسمى باكترى ايجاد مى كنند، اثــربخشى

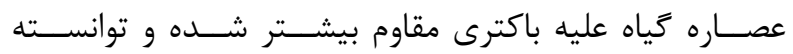

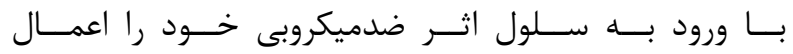
كنـــد.

يزوهش ما نشان داد خاصيت آنتى باكتريال عصاره موسير و

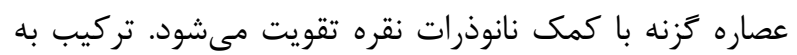
دست آمده در اين تحقيق يتانسيل اين را دارد كه در آينده بتوان عليه ساير باكترىهاى مقاوم هم به كار برد. يس إز

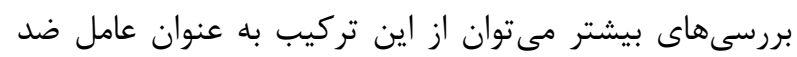

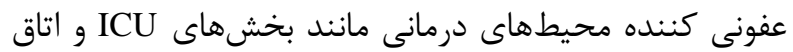
عمل و همجنين وسايل و تجهيزات استريل اتاق عمل استفاده كرد و همجنين ممكن است بتوان از اين تركيب در آينده به وسيه عنوان داروى ضد ميكروبى در درمان استفاده كرد، البته اين امر نيازمند تحقيقات گستردهترى است.

\section{تقدير و تشكر}

اين مطالعه حا صل از يايان نامه داذشجويى مقطع كار شنا سى دانى

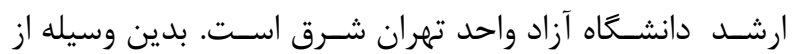
مركز تحقيقات ايمونولوزى و بيمارىهاى عفونى دانشـعاه علوم

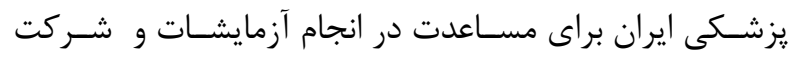
داروسازى ابن ماسويه جهت كمك در توليد عصارههاى زياهى ئى تشكر و قدردانى مىشود.
9 / / • كاهش يافتند. بنابراين مطابق با نتايج به دست آمده،

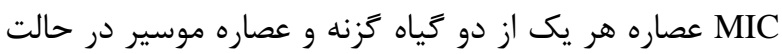
تركيبى با نانوذرات نقره عليه ايزوله كلبسيلاى سبه كمتر از MIC حالت منفرد آنها بود. به عبارت ديخر اثربخشى ضد باكتريايى آنها با كمك نانوذرات نقره افزايش يافت، كه نتايج مطالعات تعيين غلظت مهارى نسبى (FIC) نيز تاييد كننده آن است، زيرا نشان داد كه تركيب نانوذرات نقره با عصاره هر يك دئي

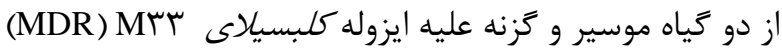
داراى اثر سينرزيسمى است. تعدادى از مطالعات اين ادعا كه تعدادى از تركيبات آلى، زمانى كه همراه با نانوذرات به به كار

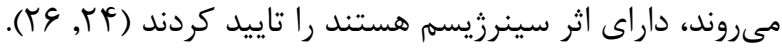
تحقيقات Heydari و همكارانش مبنى بر بررسى اثر سينرزيسم

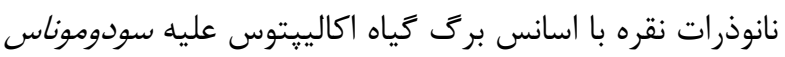

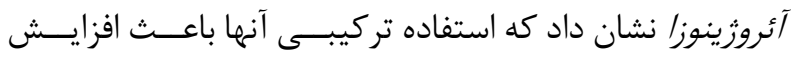
اثر خاصيت ضدباكتريايى اين تركيب بر روى سودوموناس

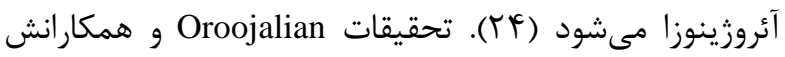
مبنى بر بررسى اثرات ضد باكتريايى تركيبى اسانس كرفس كوهى و كليوره با نانوذرات سنتزى نقره عليه باكترى هاى كرم

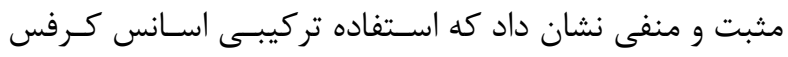

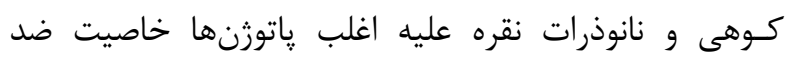
باكتريـايى بيشـترى نسبت به كاربرد انفرادى هر كدام دارد و نانوذرات نقره در تركيب با اسانس كرفس كوهى عليه باكترى -

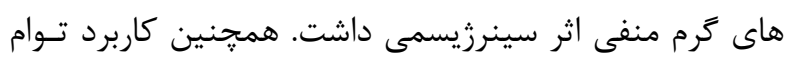

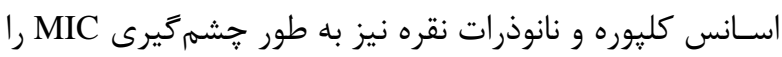
نسبت به حالت اتفرادى آنها كاهش داد (צ؟). در نهايت مى دوتوان

\section{REFERENCES}

1. Devrajani B, Shah S, Devrajani T, Qureshi GA. Nosocomial infections in medical ward (Four months descriptive study in a tertiary care hospital). World J Med Sci 2009;4:13-7.

2. Nejad SB, Allegranzi B, Syed SB, Ellis B, Pittet D. Health-care-associated infection in Africa: a systematic review. Bull World Health Organ 2011;89:757-65.

3. Bearman GM, Munro C, Sessler CN, Wenzel RP, editors. Infection control and the prevention of nosocomial infections in the intensive care unit. Seminars in respiratory and critical care medicine. New York: Thieme Medical Publishers; 2006.

4. Fridkin SK, Welbel SF, Weinstein RA. Magnitude and prevention of nosocomial infections in the intensive care unit. Infect Dis Clin North Am 1997;11:479-96.

5. Soltan Dalal MM, Miremadi SA, Sharify Yazdi MK, Rastegar Lari A, Rajabi Z, Avadis Yans S. Antimicrobial resistance trends of Klebsiella spp. isolated from patients in Imam Khomeini Hospital. Journal of Payavard Salamat 2012;6:275-81. [In Persian]

6. Kumar V, Sun P, Vamathevan J, Li Y, Ingraham K, Palmer L, et al. Comparative genomics of Klebsiella pneumoniae strains with different antibiotic resistance profiles. Antimicrob Agents Chemother 2011;55:4267-76.

7. Murray PR, Rosenthal KS, Pfaller MA, editors. Medical microbiology. New York: Elsevier Health Sciences; 2015.

8. Immanuel G, Vincybai V, Sivaram V, Palavesam A, Marian MP. Effect of butanolic extracts from terrestrial herbs and seaweeds on the survival, growth and pathogen (Vibrio parahaemolyticus) load on shrimp Penaeus indicus juveniles. Aquaculture 2004;236:53-65. 
9. Seidler RJ, Knittel MD, Brown C. Potential pathogens in the environment: cultural reactions and nucleic acid studies on Klebsiella pneumoniae from clinical and environmental sources. Appl Microbiol 1975;29:819-25.

10. Rios J, Recio M. Medicinal plants and antimicrobial activity. J Ethnopharmacol 2005;100:80-4.

11. Avato P, Tursi F, Vitali C, Miccolis V, Candido V. Allylsulfide constituents of garlic volatile oil as antimicrobial agents. Phytomedicine 2000;7:239-43.

12. Mahmoudi M, Ebrahimzadeh M, Pourmorad F, Yasini S. Antinociception and locomotor impairment induction by methanolic extract of Urtica dioica. International Journal of Biology and Biotechnology 2007;4:181-85.

13. Kvistek L, Prucek R. The preparation and application of silver nanoparticles. J Mater Sci 2005;22:2461-73.

14. Sondi I, Salopek-Sondi B. Silver nanoparticles as antimicrobial agent: a case study on E. coli as a model for Gramnegative bacteria. J colloid Interface Sci 2004;275:177-82.

15. Majd,A. Mehrabian,S and Jajary,Z. The study of antimicrobial effects of urtica dioica extract. Medicinal and Aromatic plants Res 2003; 19: 287-293. [In Persian]

16. Abdeltawab AA, Ullah Z, Al-Othman AM, Ullah R, Hussain I, Ahmad S, et al. Evaluation of the chemical composition and element analysis of Urtica dioca. Afr J Pharm Pharmacol 2012;6:1555-8.

17. Mirzajani F, Ghassempour A, Aliahmadi A, Esmaeili MA. Antibacterial effect of silver nanoparticles on Staphylococcus aureus. Res Microbiol 2011;162:542-9.

18. Stark WJ. Nanoparticles in biological systems. Angew Chem Int Ed Engl 2011;50:1242-58.

19. Kumar S, Singh M, Halder D, Mitra A. Mechanistic study of antibacterial activity of biologically synthesized silver nanocolloids. Colloids Surf A 2014;449:82-6.

20. Marambio-Jones C, Hoek EM. A review of the antibacterial effects of silver nanomaterials and potential implications for human health and the environment. J Nanopart Res 2010;12:1531-51.

21. Najjar MB, Kashtanov D, Chikindas ML. Natural antimicrobials e-poly-l-lysine and Nisin A for control of oral microflora. Probiotics Antimicrob Proteins 2009;1:143.

22. Stamdards A. Performance standards for antimicrobial susceptibility testing. CLSI 2010:M100-S20.

23. Landage S, Wasif A, Dhuppe P. Synthesis of nanosilver using chemical reduction methods. IJAREAS 2014;3:14-22.

24. Heydari MA, Mobini M, Salehi M. The synergic activity of eucalyptus leaf oil and silver nanoparticles against some pathogenic bacteria. Arch Pediatr Infect Dis 2017;5:e61654.

25. Lorian V, editor. Antibiotics in laboratory medicine. New York: Lippincott Williams \& Wilkins; 2005.

26. Oroojalian F, Orafaee H, Azizi M. Synergistic antibaterial activity of medicinal plants essential oils with biogenic silver nanoparticles. Nanomedicine Journal 2017;4:237-44.

27. Oroojalian F, Kasra-Kermanshahi R, Azizi M, Bassami MR. Phytochemical composition of the essential oils from three Apiaceae species and their antibacterial effects on food-borne pathogens. Food Chem 2010;120:765-70.

28. Romano CS, Abadi K, Repetto V, Vojnov AA, Moreno S. Synergistic antioxidant and antibacterial activity of rosemary plus butylated derivatives. Food Chem 2009;115:456-61.

29. NNIS System. National nosocomial infections surveillance (NNIS) system report, data summary from January 1992 through June 2003, issued August 2003. Am J Infect Control 2003;31:481.

30. Barak M, Mamishi S, Siadati SA, Salamati P, Khotaii G, Mirzarahimi M. Risk factors and bacterial etiologies of nosocomial infections in NICU and PICU wards of children's medical center and Bahrami Hospitals during 2008-2009. J Ardabil Univ Med Sci 2011;11:113-20. [In Persian]

31. Hazvini K, Rashed T, Boskabadi H, Yazdan Panah M, Khakzadan F, Safaee H, et al. Neonatal intensive care unit nosocomial bacterial infections. Tehran Univ Med J 2008; 66 :349-54. [In Persian]

32. Shojaei S, Rahimi T, Amini M, Shams S. Survey of Nosocomial Infections in Patients Admitted to Nekoei Hospital of Qom City in 2012, Iran. Qom Univ Med Sci J 2015; 9 :64-73. [In Persian]

33. Mehmood Z, Ahmad S, Mohammad F. Antifungal activity of some essential oils and their major constituents. Indian J Nat Prod 1997;13:10-3.

34. Roshani M, Heidary M, Goudarzi H, Hashemi A, Eslami G, Yousefi N. Investigating the antibacterial effect of methanoland acetone extracts of Urtica dioica and Zataria multifloraagainst metallo beta-lactamase producing Pseudomonas aeruginosa. JIUMS 2016;24:70-8. [In Persian] 
35. Taran M, Rezaeian M, Izaddoost M. In vitro antitrichomonas activity of Allium hirtifloium (Persian Shallot) in comparison with metronidazole. Iran J Public Health 2006;35:92-4.

36. Rai M, Deshmukh S, Ingle A, Gade A. Silver nanoparticles: the powerful nanoweapon against multidrug- resistant bacteria. J Appl Microbiol 2012;112:841-52.

37. Fong J, Wood F. Nanocrystalline silver dressings in wound management: a review. Int J Nanomedicine 2006;1:441.

38. Chen X, Schluesener HJ. Nanosilver: a nanoproduct in medical application. Toxicol Lett 2008;176:1-12.

39. Malarkodi C, Rajeshkumar S, Paulkumar K, Gnanajobitha G, Vanaja M, Annadurai G. Biosynthesis of semiconductor nanoparticles by using sulfur reducing bacteria Serratia nematodiphila. Adv Nano Res 2013;1:83-91.

40. Hajipour MJ, Fromm KM, Ashkarran AA, de Aberasturi DJ, de Larramendi IR, Rojo T, et al. Antibacterial properties of nanoparticles. Trends Biotechnol 2012;30:499-511.

41. Amin M, Kapadnis B. Heat stable antimicrobial activity of Allium ascalonicum against bacteria and fungi. Indian $\mathbf{J}$ Exp Biol 2005;43:751-54.

42. Mnayer D, Fabiano-Tixier AS, Petitcolas E, Hamieh T, Nehme N, Ferrant C, et al. Chemical composition, antibacterial and antioxidant activities of six essentials oils from the Alliaceae family. Molecules 2014;19:20034-53.

43. Franci G, Falanga A, Galdiero S, Palomba L, Rai M, Morelli G, et al. Silver nanoparticles as potential antibacterial agents. Molecules 2015;20:8856-74. 